\title{
Anna Kavan Meets a New Zealand Writer on His Special Day
}

\author{
Jennifer Sturm
}

Anna Kavan, (1901-68) prolific English writer and painter, globetrotter extraordinaire, heroin addict, and friend of conscientious objector lan Hamilton, lived on Auckland's North Shore in 1941-42. Following an unhappy childhood and two failed marriages, she was a troubled woman, given to a prevailing sense of despair if not nihilism. Her fragile grip on sanity was sustained by her writing, 'eliminating through ink' as Cocteau has said. ${ }^{1}$ The author of five books by the time she met Hamilton, she went on to write a total of nineteen books, some published posthumously, and almost all autobiographically-based works of fiction. The couple forged a relationship in England in 1939, when Hamilton's sister Margery began an affair with Kavan's husband, Stuart Edmonds. They travelled together, initially to Norway, then New York and Mexico, finally stopping in La Jolla, California, where they spent some months before parting company, Hamilton journeying back to Aotearoa/ New Zealand and Kavan travelling with a new male companion to Indonesia. Several months later, by means of some convoluted global meandering through increasingly war-torn shipping routes Kavan found her way to Auckland where she set up house with Hamilton in Torbay, then the quasi-Bohemian and least inhabited of Auckland's east coast bays.

Intrigued and delighted with her new environment Kavan observed and absorbed, writing every day, according to Hamilton. ${ }^{2}$ Her observations are recorded in an unpublished manuscript held in the McFarlin Library, University of Tulsa, Oklahoma. Kept in an archive which contains drafts and reviews of many of Kavan's published works, and presumably of limited interest to researchers who have no connection with Aotearoa / New Zealand, the manuscript has gathered metaphorical dust in the sixty-two years since it was written. It may be regarded as either a factual memoir or an autobiographically oriented collection of short stories, there being little to distinguish between the two. Subtitled 'What I remember abt N.Z.' [sic] the narratives make fascinating reading, and form the basis of my doctoral thesis, which will explore an

\footnotetext{
${ }^{1}$ Jean Cocteau. Opium. The Diary of a Cure (1929). Translated by Margaret Crosland and Sinclair Road. London: Peter Owen Publishers, 1957, p.139.

${ }^{2}$ Ian Hamilton, interview with Aorewa McLeod. Auckland, 1981. My thanks to Aorewa McLeod for making the audiotape of this interview available to me.
} 
Aotearoa / New Zealand confluence in Kavan's post-war writing. $^{3}$ Identification of the numerous personages mentioned by Kavan is proving to be a stimulating and often entertaining process.

Hamilton was an expatriate Englishman who had travelled back to his homeland hoping to achieve some success with his anti-war three-act play Falls The Shadow, prophetically written in 1936, winning the People's Theatre award when it was performed in the Auckland Town Hall. His social group in Auckland included left-wing lawyer, Frank Haigh and his wife Honey, architect Vernon Brown, photographer Clifton Firth, exiled poet Karl Wolfskehl, and many writers. The group was extremely gregarious, meeting often for company and the exchange of ideas. Kavan's identification of these people is less specific than the clue-laden portrayals she provides of her less-illustrious Torbay neighbours, indeed, in many cases, the residents of Torbay are actually named, and I have found that, in many cases, their descendants still live in the same houses.

In reading through the typewritten story 'October' my interest was piqued by the following text:

In Takapuna we saw a man whom we knew, a writer of New Zealand stories, walking along the street. $\mathrm{H}$ stopped the car at the edge of the footpath just beside the writer, who put his foot on the running board and began talking to us. Standing with his hands in his pockets and his foot on the running board, the writer began to tell us about an American publisher, who had written to him. He likes my stories, he said. He likes the New Zealand touch $[\ldots]$ Then he began quoting this thing and that thing out of the letter, demonstrating to us the high esteem in which his stories were held by the publisher [...]. The writer then went on to tell us what he intended to do when his contract was signed, how he would travel to New York and walk straight into the publisher's office and rub shoulders with all the leading writers of the United States. After he had sampled the best that New York had to offer, the writer planned to cross over to England to inspect the literary scene there. And if they pull any superior stuff I'll know the answer, he said. I'll give them clearly to understand that I'm one of the conquerors viewing the ruins of Rome and not much impressed by them either [...] We accepted all this [...] It was probably a good thing we happened to drive through Takapuna just then. The writer got a chance to tell someone about the publisher's letter and to build himself up a bit [...] I knew he never would write a full size book [...] so what difference did it make if he was too busy building himself up [...]

${ }^{3}$ The ms bears the title 'Five Months Further', covering a period of five months which relate to Kavan's decision to leave New Zealand and her eventual arrival back in England. The time frame is September 1942 to January 1943. 
to take any interest in us [...]? Finally the writer took his foot off the running board and said So long, and we said So long, and drove on, leaving the writer in Takapuna thinking perhaps that the publisher's letter really was a talisman to success.'

Is it possible that the 'New Zealand writer' could be the same New Zealand writer who, according to Michael King, his biographer, took 'afternoon strolls around the Takapuna shops'? The chronological information in Kavan's memoir dates the meeting as having taken place in October 1942. King, in Frank Sargeson. A Life notes that in 1942 Sargeson sent a copy of 'That Summer' to 'Lehmann in London [...] and another to an agent in New York named Harold Ober' [206]. King later reports that 'the American copy had arrived safely but the agent was unable to place it.' [217]

Sargeson had fostered a friendship with Hamilton, finding him to be 'charming and stimulating company'. Apart from literary and political sympathies the two men shared an interest in the soil, spending time speaking of compost and organic gardening, an interest that was to consume much of Hamilton's time following his release from prison in 1945. A socialist who was in effect a remittance man, he was well educated and from a wealthy English family. He amused the permanently impoverished Sargeson, who according to Michael King, 'joked that [...] cruising about the North Shore roads in a black sedan, cigarette holder projecting from the side of his mouth, [Hamilton] resembled nothing so much as a glamorous remittance man.' Graeme Lay recalls Sargeson's observation that Hamilton and Kavan looked alarmingly like 'a Chicago mobster and his moll.'4

In his autobiographical Never Enough Sargeson records that 'In 1946, despite paper shortages and bureaucratic controls, $\mathrm{Mr}$ John Lehmann published That Summer, and Other Stories.' Characteristically immodest, he continues, 'Say I'm conceited if you like, but from somewhere about the time of That Summer I never much doubted my own ability.' [355-6] I propose that, given the chronology, the proximity, and the social connection, the 'New Zealand writer' of whom Kavan speaks somewhat disparagingly was, indeed, Frank Sargeson.

\section{Works Cited}

Cocteau, Jean. Opium. The Diary of a Cure. (1929) Translated by Margaret Crosland and Sinclair Road. London: Peter Owen Publishers, 1957.

Kavan, Anna. 'Five Months Further' Unpublished ms. Anna Kavan Papers. McFarlin Library, U. of Tulsa, Oklahoma.

\footnotetext{
${ }^{4}$ Graeme Lay. Telephone interview with author. 27 Feb.2004.
} 
Hamilton, Ian. Audio taped interview with Aorewa McLeod, Auckland, 1981.

King, Michael. Frank Sargeson. A Life. Auckland: Viking, 1995.

Lay, Graeme. Telephone interview with author, 27 February 2004.

Sargeson, Frank. Sargeson. Auckland: Penguin Books, 1981. 